\section{References}

1 Grahame-Smith DG. The carcinoid syndrome. London: Heinemann, 1972.

2 Moetel CG, Sauer WG, Dockerty MB, Baggenstoss AM. Life history of the carcinoid tumour of the small intestine. Cancer 1961;14:901-12.

${ }^{3}$ Godwin JD 2d. Carcinoid tumours: an analysis of 2837 cases. Cancer $1975 ; 36: 560-9$.

4 Haskell CM, Tompkins RK. Carcinoid tumours. In: Haskell CM, ed. Cancer treatment. Philadelphia: WB Saunders, 1980.

5 Allison DJ, Modlin IM, Jenkins WJ. Treatment of carcinoid liver metastases by hepatic artery embolization. Lancet 1977;ii:1323-5.
${ }^{6}$ Dery R. Theoretical and clinical considerations in anaesthesia for secreting carcinoid tumours. Can Anaesth Soc f 1971;18:245-63.

${ }^{7}$ Melia WM, Nunnerly HB, Johnson PJ, Williams R. Use of devascularisation and cytotoxic drugs in 30 patients with the carcinoid syndrome. Br $\mathcal{F}$ Cancer 1982;46:331-9.

${ }^{8}$ Mays ET, Wheeler CS. Demonstration of collateral arterial flow after interruption of hepatic arteries in man. N Engl f Med 1974;290:993-6.

${ }^{9}$ Henessey $\mathrm{O}$, Allison DJ. Intrahepatic gas following embolization. $\mathrm{Br} \mathcal{F}$ Radiol (in press).

(Accepted 14 fune 1983)

\title{
Lacunar infarcts in polycythaemia with raised packed cell volumes
}

\author{
J M S PEARCE, C P CHANDRASEKERA, E J LADUSANS
}

\begin{abstract}
Lacunar (small deep cerebral infarcts) infarction is described in association with raised packed cell volumes. Two patients had polycythaemia vera, one stress polycythaemia. They presented with transient ischaemic episodes and were shown by computed tomography to have lacunes deep in the basal ganglia and internal capsule. Such lesions may be caused by small vessel occlusions related to increased viscosity and impaired oxygen consumption by adjacent tissues. Finding a raised packed cell volume in patients with lacunes and transient ischaemic attacks offers a further possibility of treatment.
\end{abstract}

\section{Introduction}

Lacunes are small $(0.5-15 \mathrm{~mm})$ infarcts in the basal ganglia, internal capsule, and basis pontis resulting from occlusion of penetrating small arteries. ${ }^{12}$ They also result from rupture of microaneurysms. Fisher examined 114 brains with lacunes and found an association with hypertension in all but one patient." We describe three patients who had lacunes in association with a raised packed cell volume due to polycythaemia, an association not previously described.

\section{Case reports}

Case 1-A 66 year old man had a two year history of sudden attacks of tingling in the left forearm with difficulty in grip for three minutes, averaging six attacks a year. There were no features affecting the face, speech, vision, or leg. Five weeks before admission he lost control of his legs, wobbled and staggered, but recovered in three minutes. He was alert with no plethora; the blood pressure was $130 / 80 \mathrm{~mm} \mathrm{Hg}$ in both arms; the heart and chest were normal. The liver was four finger breadths enlarged and the spleen was palpable. No neurological

\footnotetext{
Department of Neurology, Hull Royal Infirmary, Hull HU3 2JZ

J M S PEARCE, MD, FRCP, consultant neurologist

C P CHANDRASEKERA, MB, MRCP, registrar

E J LADUSANS, MB, MRCP, senior house officer

Correspondence to: Dr J M S Pearce.
}

abnormality was detected apart from heel-shin ataxia in the left leg. Investigations showed a normal chest $x$ ray film; haematological values are shown in the table. Biochemical profile, liver function tests, and coagulation profile were normal. Diagnostic sonar confirmed enlargement of the liver and spleen. Bone marrow showed marrow particles of increased cellularity; all three cell lines were very active with prominent megakaryocytes, the iron stores being reduced. These appearances were compatible with polycythaemia vera. $\mathrm{He}$ was treated with venesection and later with ${ }^{32} \mathrm{P}$.

Haematological values in the three patients

\begin{tabular}{lccc}
\hline \multicolumn{1}{c}{ Values } & Case 1 & Case 2 & Case 3 \\
\hline Haemoglobin $(\mathrm{g} / \mathrm{dl})$ & 17.6 & $17 \cdot 7$ & 18.0 \\
Red cell count $\left(\times 10^{12} / \mathrm{l}\right)$ & 17.6 & 6.34 & 5.90 \\
Packed cell volume & 0.55 & 0.572 & 0.539 \\
White cell count $\left(\times 10^{9} / 1\right)$ & 9.5 & 13.3 & 6.9 \\
Platelets $\left(\times 10^{\natural} / 1\right)$ & 883 & & 315 \\
Erythrocyte sedimentation & $<1$ & $<1$ & 1 \\
rate $($ mm in $1 \mathrm{st} \mathrm{h})$ & & 1 \\
Red cell volume $(\mathrm{ml} / \mathrm{kg})$ & 32 & & 33 \\
Plasma volume $(\mathrm{ml} / \mathrm{kg})$ & 33 & & \\
\hline
\end{tabular}

Case 2-A 66 year old male calligrapher presented with two episodes of transient weakness of his left arm and left leg; he had difficulty formulating written letters, with occasional hesitancy in speech and poor verbal memory. Polycythaemia vera had been diagnosed at another hospital (table), and he had been treated with $4 \mathrm{mCi}$ of ${ }^{32} \mathrm{P}$. His blood pressure was $170 / 100 \mathrm{~mm} \mathrm{Hg}$, the heart and chest being normal. There were no carotid bruits. His liver was enlarged three finger breadths; the spleen was not felt. He had a left sided homonymous hemianopia, dysgraphia, and nominal dysphasia. Computed tomography showed bilateral lacunes (fig 1 ).

Case 3-A 49 year old man first presented with sudden dizziness, slurred speech, and clumsiness while walking. His general practitioner found that he had a blood pressure of $210 / 115 \mathrm{~mm} \mathrm{Hg}$ and grade II hypertensive retinopathy and treated him with atenolol and hydralazine. A month later he complained of episodic paraesthesiae in the left arm, face, and leg with slurred speech. He smoked 15 cigarettes a day. At hospital he was found to be plethoric with a blood pressure of $150 / 100 \mathrm{~mm} \mathrm{Hg}$. His heart, chest, and abdomen were all normal. The peripheral pulses were normal with no bruits in the neck. Fundi showed grade II hypertensive retinopathy. There was minimal ataxia of fine movement of the left hand, but no other abnormal signs. Haematological values are shown in the table. Stress polycythaemia was diagnosed, and computed tomography showed a lacune in the right thalamus (fig 2). He was treated by repeated venesection. 

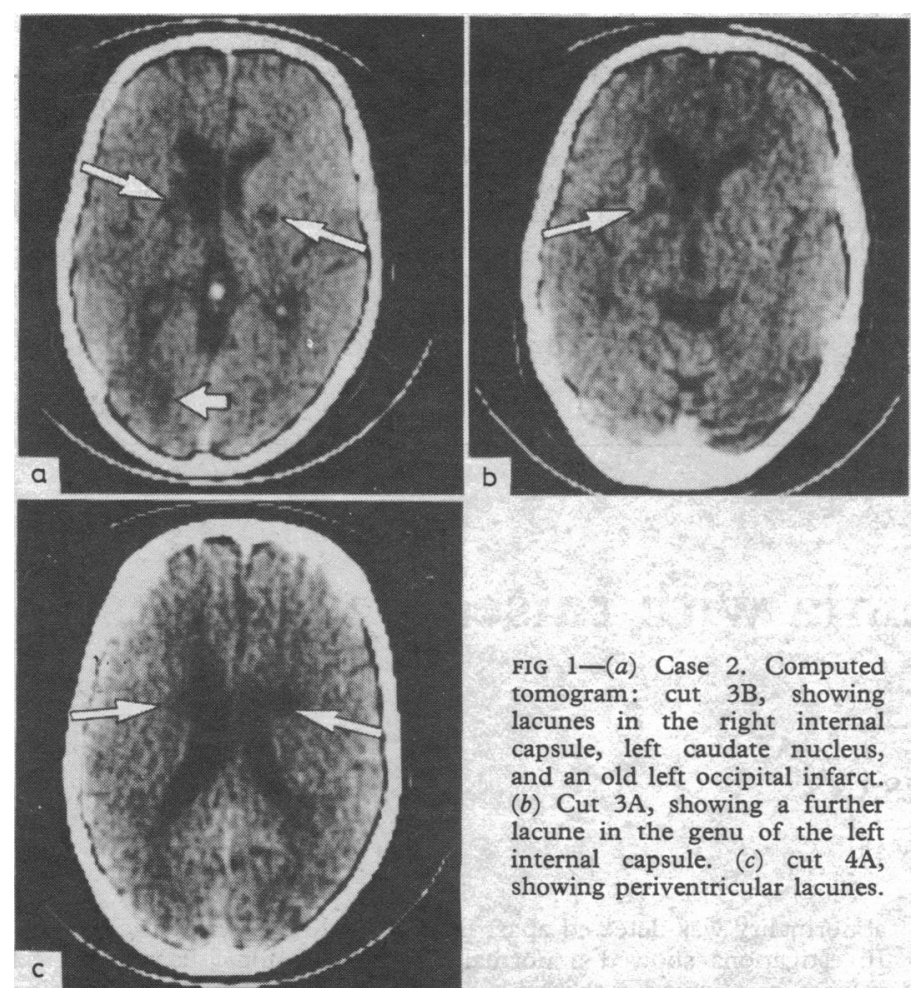

FIG $1-(a)$ Case 2, Computed tomogram: cut $3 \mathrm{~B}$, showing lacunes in the right internal capsule, left caudate nucleus, and an old left occipital infarct. (b) Cut $3 \mathrm{~A}$, showing a further lacune in the genu of the left internal capsule. (c) cut $4 \mathrm{~A}$, showing periventricular lacunes.

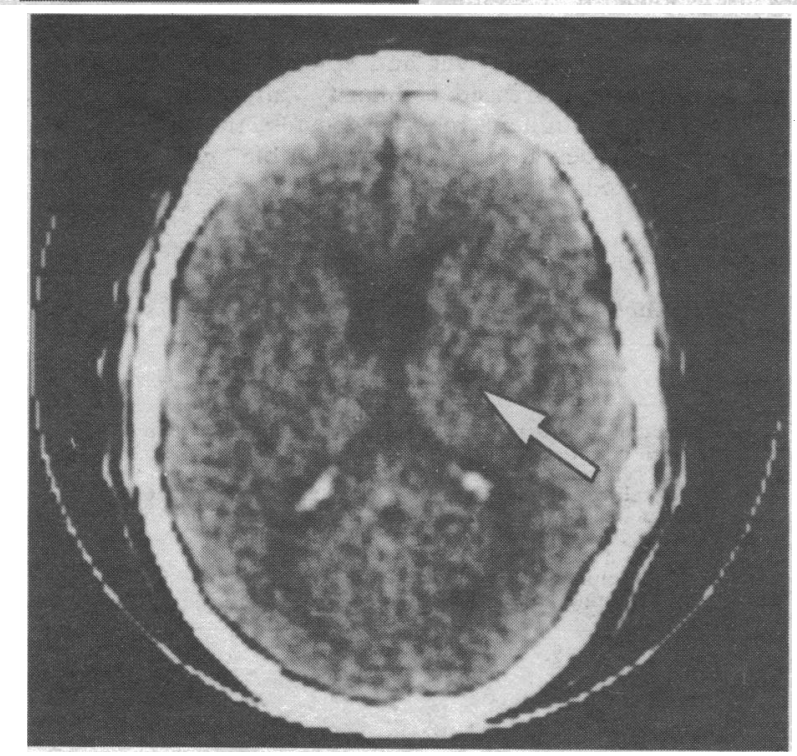

FIG 2-Case 3. Computed tomogram, cut $92 \mathrm{~B}$, showing a lacune in the right thalamus.

\section{Discussion}

Neurological disorders associated with polycythaemia include transient ischaemic attacks, cerebral infarction, and cerebral haemorrhage. ${ }^{34}$ Less specific symptoms include dizziness, paraesthesiae, visual disturbances, tinnitus, and headache explained on the basis of reduced cerebral blood flow and increased blood viscosity. Fluctuating dementia, confusional states, and choreic syndromes attributed to multiple small vessel occlusions in the cortex and basal ganglia have also been recorded. ${ }^{4}$ The pathological lesions are "not distinctive." 3

Our three patients presented with transient neurological symptoms, had raised packed cell volumes, and showed small infarcts in the region of the basal ganglia on computed tomography. Their size and distribution indicate lacunar infarction. The packed cell volume is the main determinant of blood viscosity, which may be increased five to seven times in polycythaemia. An inverse relationship between cerebral blood flow and the packed cell volume has been shown in polycythaemia. ${ }^{6}$ Cerebral blood flow is significantly reduced in polycythaemia ${ }^{5}$ and predisposes to thrombus formation; it impairs normal uptake of oxygen by tissues and impairs the microcirculation. Two of our patients had mild hypertension, an important determinant of lacunes, but one was normotensive. In these patients we speculate that the raised packed cell volume was an important contributory factor.

The recognition of lacunes in polycythaemia and states where the packed cell volume is raised is important for three main reasons. Firstly, it offers another possible mechanism of causation of cerebral symptoms in such disorders. This would be an indication for computed tomography in such patients, since $50 \%$ of lacunes may be seen with this technique. Secondly, lacunar strokes carry a better prognosis than cerebral thrombosis and haemorrhage. Thirdly, reduction of the raised packed cell volume may prevent the reoccurrence of further vascular lacunar incidents.

We thank Dr C G L Raper and Dr D A Montgomery for haematological reports and Mrs M Farmery for secretarial help in the preparation of this paper.

\section{References}

${ }^{1}$ Fisher CM. Lacunar strokes and infarcts: a review. Neurology (Minneapolis) $1982 ; 32: 871-6$.

2 Fisher CM. Lacunes. Small, deep cerebral infarcts. Neurology (Minneapolis) $1965 ; 15: 774-84$.

${ }^{3}$ Silverstein A, Gilbert H, Wasserman LR. Neurologic complications of polycythemia. Ann Int Med 1962;57:909-16.

4 Ross Russell RW. Cerebral arterial diseases. Edinburgh: Churchill Livingstone, 1976:298-9.

5 Thomas DJ. Haematological aspects of cerebral arterial disease. In: Ross Russell RW, ed. Vascular disease of the central nervous system. 2nd ed. Edinburgh: London: Churchill Livingstone, 1983:337-53.

${ }^{6}$ Thomas DJ. The influence of blood viscosity on cerebral blood flow and symptoms. In: Greenhalgh RM, Rose FC, ed. Progress in stroke research. London: Pitman, 1979:47-55.

(Accepted 20 May 1983)

ONE HUNDRED YEARS AGO A curious instance has just been brought to light of the contamination with sewage-matter of a well that has long enjoyed a high reputation for its salutary virtues. When visiting in the south of Scotland lately, Dr. Crichton Browne, who, like all good Scotchmen, is a devoted admirer of Burns, made a pilgrimage to the Brow Well, a small village on the shores of the Solway Firth, where the great national poet, by the advice of his medical attendant, spent the last fortnight of his life in a despairing effort to repair his shattered health. Struck by the character of the water of the Brow Well, and by the accounts which he received of its beneficial effects in gastric, renal, and nervous affections, Dr. Crichton Browne determined to have it analysed; and, for that purpose, sought the aid of Professor Dewar, at the Royal Institution. Professor Dewar's analysis shows the water to be of an unique description, and suggests that it may have valuable medicinal properties; but, at the same time, it reveals the fact that it is strongly tinctured with sewage. It seems probable that the drainage from the adjoining cottages and pigsties, and from the heavily manured lands in the neighbourhood, finds its way into the well. Professor Dewar thinks that it ought to be closed, in the interests of the community, until means can be taken to insure its purification. As large numbers of invalids resort to it at this season of the year, and drink freely of the water, of which the regulation quantity is six pints per diem, notice of its impurity has been given in the local papers; and application will be made to Lord Mansfield, on whose property the well is situated, to refuse access to it in the meantime, as it is feared that the class of people who are in the habit of drinking it would still continue to do so, in spite of its condemnation-trusting to their rustic tradition rather than to scientific experiment-unless forcibly excluded from it. (British Medical fournal, 1883;ii:388.) 